\title{
4.9 Тайм-менеджмент та його роль в системі дистанційного навчання закладу освіти
}

Навчання в закладах освіти - один із найважливіших періодів життя сучасної молодої людини, особистісного росту і становлення ії як фахівця. В більшості навчальних закладів здобувачі освіти не володіють необхідними для навчання i життя методами i навичками самоорганізації. Організація навчального процесу є проблемою, від вирішення якої залежить успішність у навчанні та подальшій кар'єрі майбутнього фахівця. Вирішення поставленого завдання потребує розроблення та впровадження нових шляхів успішної адаптації до змінених соціальних умов і нової діяльності. Все це вимагає від учасників навчального процесу значної мобілізації власних можливостей для успішного входу в нове оточення і якісно інший ритм життєдіяльності. В процесі адаптації до соціальних змін у молоді, що навчається, відбувається формування стійких механізмів комунікативної взаємодії із середовищем. Головним помічником в організації навчального процесу його може стати таймменеджмент - окремий напрям менеджменту, спрямований саме на вирішення проблем організації часу та встановлення пріоритетів при його використанні. Тайм-менеджмент допомагає визначити, що є головним і потребує організації, планування, а що - другорядним, допомагає контролювати власний час, розпоряджатися ним. Недостатня увага до тимчасової організації розумової праці завдає серйозної шкоди здоров'ю і негативно позначається на навчальних досягненнях здобувачів освіти.

Нещодавня доктрина розвитку освіти в Україні підкреслила необхідність рівного доступу до якісної освіти для усіх громадян. Основною вимогою сучасної якісної освіти є застосування електронних та інтернет-орієнтованих засобів у навчанні. Проблема дистанційного навчання в українській освіті набула широкого вивчення, проте зі швидкою зміною вимог до сучасних технологій навчання $є$ нестача повної інформації про вплив мотиваційних факторів на успішність дистанційного навчання. Закон України «Про освіту» наголошує на 
THEORETICAL FOUNDATIONS OF THE FUNCTIONING OF EDUCATION. WAYS TO IMPROVE THE EFFECTIVENESS OF EDUCATIONAL ACTIVITIES

інформаційному забезпеченні освітнього процесу навчального закладу, як стандарту освітньої діяльності [282]. У цьому вимірі виникає питання збереження мотивації учасників освітнього процесу при дистанційному навчанні 3 метою отримання якісного результату. Тайм-менеджмент в закладах освіти здійснювався структурованою вертикаллю - фахівцями 3 відповідними посадовими зобов'язаннями та навиками. 3 переходом до дистанційної форми навчання, доводиться перелаштовувати і цю вертикаль, з метою збільшення автономії всіх учасників навчального процесу. Але така автономія дає і негативні наслідки, зокрема розпорошення уваги між навчальним контентом та багаточисленним інструментарієм дистанційного навчання.

Одним з пріоритетних напрямів програми модернізації загальноосвітньої та вищої школи визнане дистанційне навчання. В сучасних умовах існує потреба отримання вищої освіти дистанційно, що викликано необхідністю навчатися без відриву від виробництва, отримання освіти людьми 3 обмеженими можливостями та тими, що перебувають за кордоном тощо. Таку можливість надає дистанційне навчання, яке здійснюється завдяки інформаційно-освітнім технологіям і системам комунікації [283]. Дистанційна форма навчання має ряд беззаперечних переваг. Наприклад, здобувач вищої освіти може навчатися у зручний для нього час, звичному оточення та у відносно автономному темпі. Варто врахувати також і нижчу вартість такого навчання, оскільки відпадає потреба в оренді та утриманні приміщень, оплаті значної кількості персоналу, та економію часу [284].

Проте, система дистанційного навчання має і недоліки. При тривалому дистанційному навчанні здобувач освіти перестає правильно формулювати свої думки, висловлюватись та проводити дискусійне обговорення. Разом з тим, така форма навчання потребує свідомого і вмотивованого підходу до отримання освіти. Можливість навчатися у зручний час може перетворитися не на систематичне навчання, а на постійну прокрастинацію цього виду діяльності. Саме тому дистанційна форма потребує особливої самоорганізованості та вміння 
THEORETICAL FOUNDATIONS OF THE FUNCTIONING OF EDUCATION. WAYS TO

IMPROVE THE EFFECTIVENESS OF EDUCATIONAL ACTIVITIES

розрахувати свій час. I наразі, актуальним в самоорганізації постає таймменеджмент.

В повсякденному житті кожна людина стикається із проблемою розподілу свого часу. Розуміння того, що таке тайм-менеджмент та якими є його принципи, дозволяє не лише досягати цілей з мінімальними зусиллями, а й у потрібні терміни [285].

Тайм-менеджмент - це раціональний розподіл годин в добі так, щоб і все встигнути, і спати повноцінні 7-8 годин, і бути ефективним, i залишатися здоровим. Це управління часом. Це така навичка, яку варто «прокачувати» постійно.

В управлінні часом можна визначити такі процеси:

- Аналіз.

- Моделювання стратегій, враховуючи проведений аналіз.

- Цілепокладання: постановка мети або визначення ключового напрямку розвитку. Визначення та формулювання мети (цілей).

- Планування і розстановка пріоритетів. Розробка плану досягнення поставлених цілей і виділення пріоритетних (першочергових) завдань для виконання.

- Реалізація - конкретні кроки та дії відповідно до наміченого плану і порядку досягнення мети.

- Контроль за досягненням мети, виконанням планів, підведення підсумків за результатами проведеної роботи.

Міфи про «Тайм-менеджмент»:

- Міф 1. Тайм-менеджмент — це розпланувати день похвилинно.

- Міф 2. Є універсальні поради з управління часом, які підходять усім.

- Міф 3. Тайм-менеджмент не для творчих людей.

Розвіюючи ці міфи, потрібно чітко розуміти якою $є$ кінцева мета, а відповідно - виділити головні завдання. У цьому доречно буде звернутися по допомогу до піраміди Франкліна (Рис. 1). 


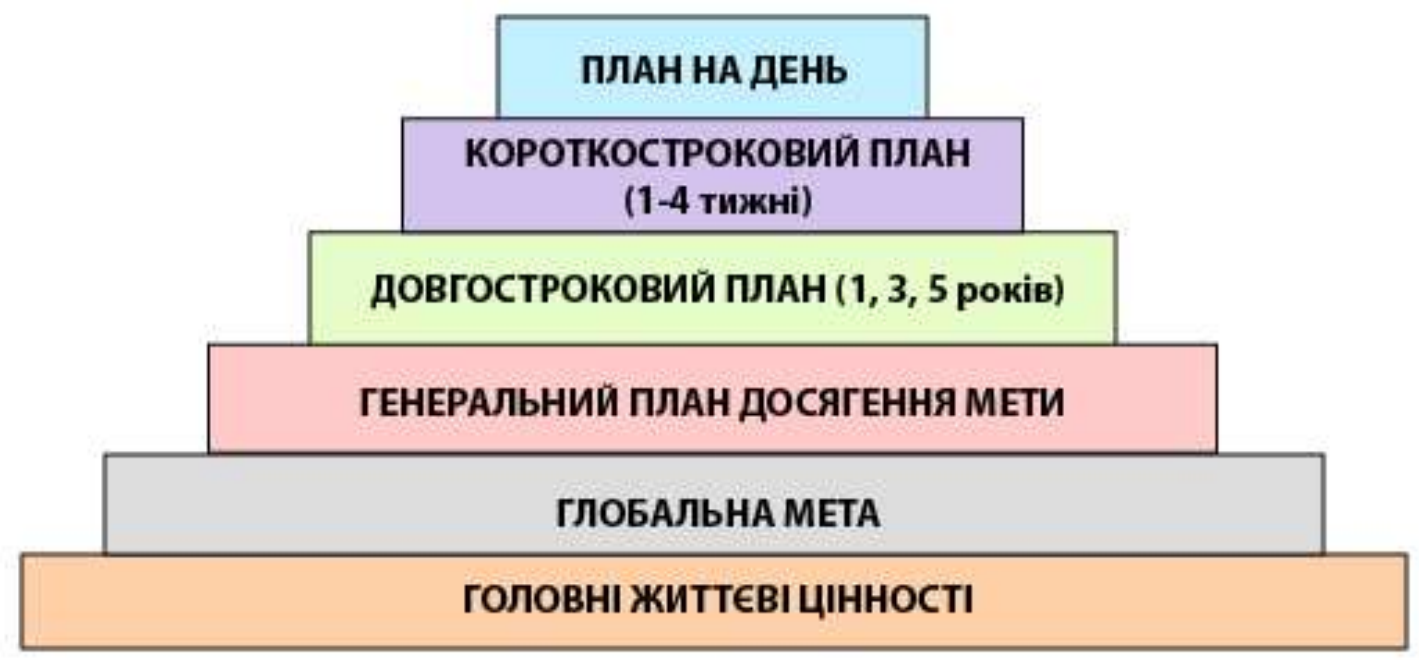

Рис. 1. Піраміда Франкліна

Піраміда Франкліна (ії також називають пірамідою ефективності) - це комплексна система постановки і досягнення цілей, яка розрахована на все життя. Відмінність піраміди Франкліна від інших методик у тому, що вона планує не тільки час, але і зайнятість, шляхи досягнення глобальної мети.

Ця техніка «спрямована в майбутнє» - визначає те, що повинно бути зроблено, а не концентрується на перегляді поточної діяльності, щоб організувати іï ефективніше. Наразі лише 1\% людей можуть точно сказати, чого вони хочуть досягти в житті. Але Франклін ще в юності склав план досягнень і намагався його виконувати. Суть полягала в наступному: глобальне завдання розбивалося на більш дрібні, а ті, в свою чергу, ще на дрібніші. Це - основна ідея піраміди Франкліна [286].

Заповнювати їі потрібно знизу вгору. Так ви сформулюєте глобальні цілі, виходячи з життєвих цінностей. Генеральний план - виходячи з глобальної мети і так далі. I так серед щоденних завдань легко буде виділити ті, які потрібні для досягнення ваших цілей. Вони і стануть пріоритетними.

Якщо застосувати піраміду Франкліна у системі дистанційного навчання, то можна виокремити наступне:

- Перелік навчальних предметів. Здобувачу освіти важливо знати повний перелік навчальних предметів, що вивчатимуться протягом певного періоду (наприклад, року). 
- Кожен предмет важливий, кожному предмету відповідна кількість годин. Кожен предмет повинен містити перелік тем та загальну кількість годин на іï вивчення.

- Кожна година (урок, заняття) значима і використати ії треба максимально ефективно (план уроку, заняття).

3 метою економії часу та зменшення ефекту «розпорошування уваги» було б доцільно прийняти в закладі освіти:

- Чіткі правила роботи он-лайн (одні для всіх).

- «Єдину точку входу» - інструментів для здійснення дистанційного навчання дуже багато, але всі учасники навчального процесу мають знати звідки починається кожен навчальній день (урок).

- Визначення платформ для ведення дистанційного навчання (з урахуванням побажань викладачів та здобувачів освіти).

Однією з головних навичок для здобувачів освіти є «вміння вчитись», саме ця навичка виходить на перший план в дистанційному навчанні. I для його успішного опанування пропонується «Дорожня карта» для того, хто навчається:

1. Структура навчального процесу (загальний об'єм).

2. Навчальний план (план курсу).

3. Чіткий розклад (кількість занять, тривалість, платформа, тип заняття).

4. Домашнє завдання, правила та рекомендації щодо його виконання.

5. Оцінювання домашнього завдання.

6. Самооцінка

У системі дистанційного навчання для кожного домашнього завдання необхідні чіткі рекомендаційні поради, можливо із написанням відповідних інструкцій, щодо їх виконання. Такий чіткий план дозволить здобувачу освіти зосередитися на виконанні завдання, а не витрачати час на «здогадування» «Що», «Де» i «Як» виконувати.

Прикладом такої чіткої інструкції можуть бути наступні вимоги/рекомендації:

1. Відкрити файл ... 
2. Вирішити, розв'язати ...

3. Доповнити завдання (відповідь) авторським рішенням...

4. Приєднати файл....

5. Здійснити самооцінку в табелі просування...

В процесі дистанційного навчання важливим $є$ контроль знань. Для закріплення навчального матеріалу та контролю знань бажано використовувати тестові завдання різних типів:

- тренувальні тести - безліч спроб надання відповідей, миттєве отримання оцінки, можливість бачити правильні відповіді;

- підсумкові тести - контроль знань з однієї спроби надання відповіді, миттєве отримання оцінки.

Цікавим і корисним для застосування тайм-менеджменту у дистанційному навчанні може бути матриця Ейзенхауера.

Матриця Ейзенхауера - це відмінна модель для розстановки пріоритетів. За iï допомоги можна виділити найважливіші завдання, відсіявши все зайве. Сенс цієї моделі полягає у швидкому розсортуванні списку справ, навіть якщо їх багато. Зовні все виглядає гранично просто - дивимося на список завдань і по кожному відповідаємо собі на два питання: 1) Це важливо? - Так / ні; 2) Це терміново? - Так / ні (Рис. 2).

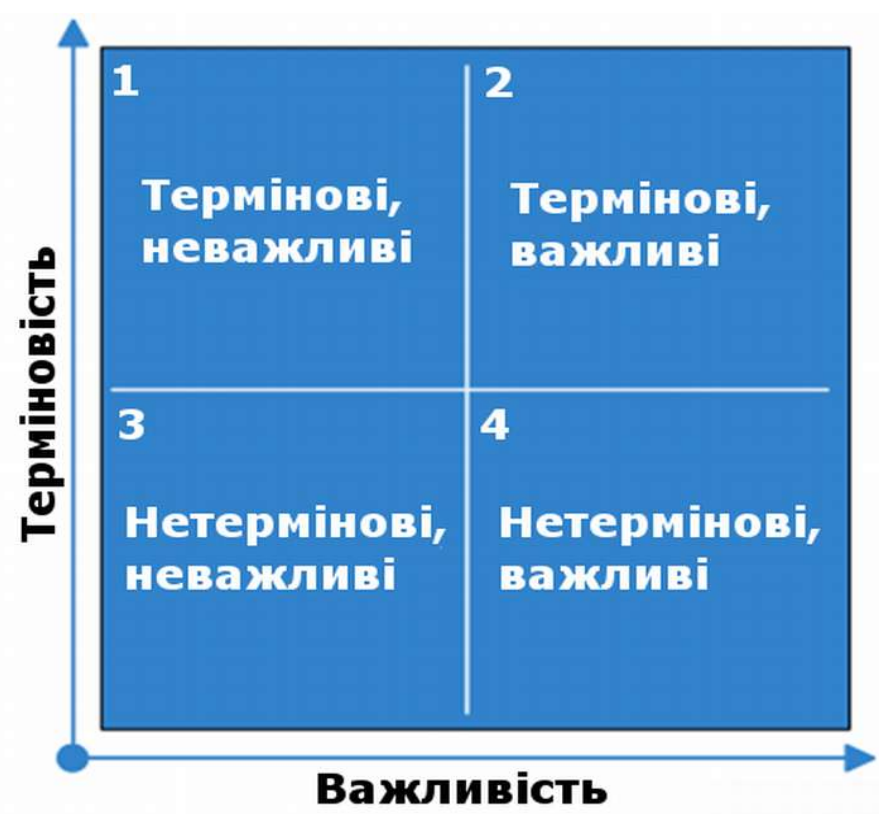

Рис. 2. Матриця Ейзенхауера 
Сенс матриці Ейзенхауера полягає в оцінці конкретного завдання по параметрам важливості / терміновості і сортуванні списку справ за цим принципом. 3 якою метою це використовується на практиці? Тут є два варіанти:

- Планування. Дуже часто людина орієнтується в першу чергу на дедлайни завдання, забуваючи оцінити їх необхідність. Даний метод допоможе зосередити свої сили на тих речах, які дійсно будуть наближати до поставленої мети.

- Оцінка особистої ефективності. Якщо в кінці тижня або місяця заносити в таблицю виконані завдання, то таким чином можна проаналізувати своє вміння розставляти пріоритети. I зрозумівши, які помилки були допущені, - більш конструктивно спланувати свої справи на наступний відрізок часу [287].

Одним із найважливіших завдань будь-якого закладу освіти при використанні системи дистанційного навчання, є дії, спрямовані на швидку й успішну адаптацію до такої форми навчання, ефективне формування соціальних відносин, освоєння нової ролі як викладачами, так і здобувачами освіти.

На ефективність адаптації учасників навчального процесу до дистанційного навчання у закладах освіти впливає такий фактор, як вміння керувати своїм часом. I тут в нагоді буде трактування сутності поняття «тайм-менеджмент» на основі піраміди Франкліна та матриці Ейзенхауера. Бо, саме використання таймменеджменту - це крок до покращення продуктивності навчання, який надає можливість ефективно спланувати свій розпорядок дня, тижня i процесу навчання в цілому. Недотримання планів і невиконання поставленої мети призводить до постійної нестачі часу, зниження мотивації i, як наслідок, негативного результату процесу навчання. 